\title{
PEMBELAJARAN IPS BERORIENTASI REVOLUSI INDUSTRI 4.0 MELALUI INFUSING BLENDED LEARNING DI SEKOLAH MENEGAH PERTAMA
}

\author{
${ }^{1}$ Sujarwo, ${ }^{2}$ Tubagus Ali Rachman \\ Pendidikan IPS, Universitas Negeri Jakarta, J1. Rawanagun Muka Jakarta, Indonesia \\ ${ }^{1}$ sujarwo-fis@unj.ac.id \\ 2tubagus.ali.rachman@metrouniv.ac.id
}

\begin{abstract}
The purpose of this research is to develop a learning model that is in accordance with the demands of the times in the industrial revolution era 4.0. Which has an impact on the shifting paradigm of learning patterns, namely learning patterns that use technology with learning that does not use technology, as well as the differences in learning concepts in class to be digital learning that doesn't have to be always in the classroom. This research uses the Research and Development approach by grouping it into three stages, namely: 1) Preliminary Study, 2) Program planning and preparation and 3) program trials. This research was conducted at 92 Jakarta Junior High School, in the even semester of the 2019/2020 Academic Year. The sampling technique in this study was a by purpose sampling by taking a sample of a group of students in class VII Junior High School 92 Jakarta. The results of this study develop a model of infusing blended learning carried out using cooperative and contextual learning models with a scientific approach and integrating or incorporating digital information technology into learning to use Google Classroom and kahoot! managed to improve student's learning outcomes and student's learning activeness. So, it can be concluded that the use of the blended learning model of learning by integrating Google Classroom and kahoot! in social studies learning is in accordance with the 4.0 industrial revolution which is characterized by the use of internet-based information technology and can be used as an alternative for teachers in learning innovation.
\end{abstract}

Key Word: Industry Revolution 4.0, Infusing Blended Learning, Social Studies

\begin{abstract}
Abstrak
Tujuan penelitian ini dalah untuk mengembangkan model pembelajaran yang sesuai dengan tuntutan zaman di era revolusi industri 4.0. yang telah membawa dampak pada bergesernya paradigma pola pembelajaran, yakni pola pembelajaran yang menggunakan teknologi dengan pembelajaran yang tidak menggunakan teknologi, serta adanya perbedaan konsep pembelajaran di kelas (classroom setting) menjadi pembelajaran digital yang tidak harus selalu di kelas. Penelitian ini menggunakan pendekataan Reseach and Development dengan mengelompokan menjadi tiga tahapan, yaitu : 1) Studi Pendahuluan, 2) Perencanaan dan penyusunan program dan 3) uji coba program. Penelitian ini dilaksanakan di SMP Negeri 92 Jakarta, pada semester genap Tahun Pelajaran 2019/2020. Teknik pengambilan sampel dalam penelitian ini adalah dengan cara purposive sampling dengan mengambil sampel satu rombongan belajar pada kelas VII SMP Negeri 92 Jakarta. Hasil penelitian ini mengembangkan model infusing blended learning dilakukan dengan menggunakan model pembelajaran kooperatif dan kontekstual dengan pendekatan saintifik dan mengintegrasian atau memasukkan teknologi informasi digital ke dalam pembelajaran dengan menggunakan google classroom dan kahoot! berhasil meningkatkan hasil belajar peserta dan keaktifan belajar peserta didik. Sehingga dapat disimpulkan bahwa penggunaan model pembelajaran infusing blended learning dengan mengintegrasikan google classroom dan kahoot! dalam pembelajaran IPS telah sesuai dengan revolusi industri 4.0 yang dicirikan dengan penggunaan teknologi informasi berbasis internet dan dapat dijadikan alternatif bagi guru dalam melakukan inovasi pembelajaran.
\end{abstract}

Kata Kunci: Revolusi Industri 4.0, Infusing Blended Learning, IPS 


\section{Pendahuluan}

Revolusi Industri 4.0 telah membawa dampak pada bergesernya paradigma pola pembelajaran, yakni pola pembelajaran yang menggunakan teknologi dengan pembelajaran yang tidak menggunakan teknologi, serta adanya perbedaan konsep pembelajaran di kelas (classroom setting) dengan pembelajaran terbuka atau pembelajaran digital yang tidak harus selalu di kelas. Model tersebut memiliki perbedaan dari segi gaya mengajar, teknik serta motivasi pembelajar dan pengajar sesuai dengan tuntutan perkembangan ilmu pengetahuan dan teknologi. Revolusi Industri 4.0 menuntut agar materi pembelajaran dapat dikemas secara elektronik dan dimasukkan ke dalam jaringan sehingga dapat diakses melalui pembelajaran digital. Oleh sebab itu, pendidik perlu memiliki kemampuan mengelola dengan baik penyelenggaraan kegiatan pembelajaran digital melalui internet. Namun pada kenyataannya, sangat sulit bagi perguruan tinggi untuk dapat melaksanakan pembelajaran digital yang seluruh proses pembelajarannya dilaksanakan dengan online learning secara terus menerus.

Pengembangan model pembelajaran yang relevan dan sesuai dengan tuntutan dan perkambangan revolusi industri 4.0 sangat penting mengingat arus digitalisasi dan penggunaan internet telah merubah pola pendidikan dan paradigma pembelajaran yakni dalam pengemasan materi pembelajaran dilakukan secara elektronik dan dimasukkan ke dalam jaringan sehingga dapat diakses melalui pembelajaran digital.

Namun demikian berdasarkan analisis empirik terhadap kondisi pembelajaran sekarang yang masih banyak yang bersifat konvensial (classical learning class) sehingga memerlukan suatu alternatif pemecahan menjembatani persoalan-persoalan seputar proses pembelajaran di era revolusi industri 4.0. Oleh sebab itu diperlukan pengembangan model pembelajaran yang sesuai dengan kemajuan bidang teknologi informasi. Penelitian Muhammad dan Tetep (2018) mengenai penerapan media Kahoot dalam pembelajaran PPKn mampu meningkatkan ketertarikan dan motivas siswa dalam pembelajaranya. Media ini bisa digunakan secara blended.

Diperlukan infusing dengan mengengintegrasikan dan memasukkan Teknologi Informasi dan Komunikasi (TIK) ke dalam pembelajaran, yakni guru mengeksplorasi suatu cara atau metode baru dimana TIK diupayakan digunakan dalam pengelolaan pembelajaran untuk meningkatkan belajar siswa yang dilakukan melalui istilah yang disebut dengan blended learning yang diartikan sebagai pembelajaran campuran yang mengandung unsur pencampuran atau penggabungan antara satu pola dengan pola yang lainnya dalam pembelajaran, yakni pembelajaran di kelas (classroom lesson) dengan online learning (Wasis: 2018).

Penelitian yang dilakukan oleh Wright (2017) tentang pengggunaan blended learning dalam pembelajaran mengindikasikan bahwa siswa lebih suka pada pembelajaran online karena memiliki kecepatan dan kenyamanan belajar dan fleksibilitas waktu dan tempat belajar. Dengan adanya persepsi yang baik tersebut, tentu saja dapat dijadikan dasar bagi pendidik untuk dapat mengembangkan model blended learning dalam pembelajaran yang dilakukan. Selian itu, penelitian Centinkaya (2016) menjelaskan bahwa pembelajaran dengan blended learning dapat mempermudah guru dalam menjelaskan konsep dalam pembelajaran.

Oleh sebab itu untuk mengatasi masalah pembelajaran di era revolusi industri 4.0 tersebut maka diperlukan upaya mengembangkan pembelajaran blended learning (campuran antara pembelajaran online dan tatap muka). Blended learning merupakan pilihan untuk meningkatkan efektivitas, efisiensi, dan daya tarik yang lebih besar dalam berinteraksi antara peserta didik dan pendidik. Blended learning menawarkan kesempatan belajar untuk menjadi baik secara bersama-sama dan terpisah, pada waktu yang sama maupun berbeda. Sebuah kelas belajar dapat dilakukan oleh peserta didik dan pendidik yang dapat berinteraksi setiap saat dan di mana saja dengan memanfaatkan komputer maupun perangkat lain (seperti smartphone) sebagai fasilitasi 
belajar. Berdasarkan pemikiran tersebut, penelitian ini secara umum bertujuan untuk mengembangkan model pembelajaran yang berorientasi pada revolusi industri 4.0 dengan menggunakan blended learning.

\section{Metode Penelitian}

Penelitian ini menggunakan metode penelitian dan pengembangan (reseach and development). Peneliti mengelompokan menjadi tiga tahapan, yaitu : 1) Studi Pendahuluan, 2) Perencanaan dan penyusunan program dan 3) uji coba program. Penelitian ini dilaksanakan di SMP Negeri 92 Jakarta, pada semester genap Tahun Pelajaran 2019/2020. Teknik pengambilan sampel dalam penelitian ini adalah dengan cara purposive sampling. Berdasarkan teknik sampling tersebut maka peneliti mengambil sampel 1 rombongan belajar pada kelas VII SMP Negeri 92 Jakarta.

Teknik pengumpulan data yang digunakan dalam penelitian ini adalah; 1) observasi, 2) angket, 3) wawancara dan 4) dokumentasi. Analisis data yang digunakan dalam penelitian ini menyesuaikan dengan data yang diperoleh di lapangan. Adapun analisis data yang digunakan yaitu: Untuk data berupa hasil pengamatan, dokumentasi dan wawancara serta hasil uji coba, maka akan dilakukan analisis data secara kualitatif dengan pemaparan naratif, sedangkan untuk data kinerja guru dan kemampuan belajar siswa serta hambatannya, maka teknik analisis data yang digunakan adalah dengan menggunakan statistik deskriptif.

\section{HASIL DAN PEMBAHASAN}

Berkaitan dengan pembelajaran blended learning dalam pembelajaran Ilmu Pengetahuan Sosial dalam penelitian ini adalah dengan menggunakan media kahoot! dan google classroom sebagai ketika proses pembelajaran berlangsung. Kahoot! merupakan sebuah aplikasi yang dapat digunakan sebagai sebuah permainan maupun pembelajaran. Aplikasi ini dapat dapat diakses dengan menggunakan smartphone yang terkoneksi dengan internet.

Berdasarkan implementasi pada uji coba terbatas yang telah dilakukan maka desain pembelajaran pembelajaran Ilmu Pengetahuan Sosial dalam penelitian ini adalah sebagai berikut :

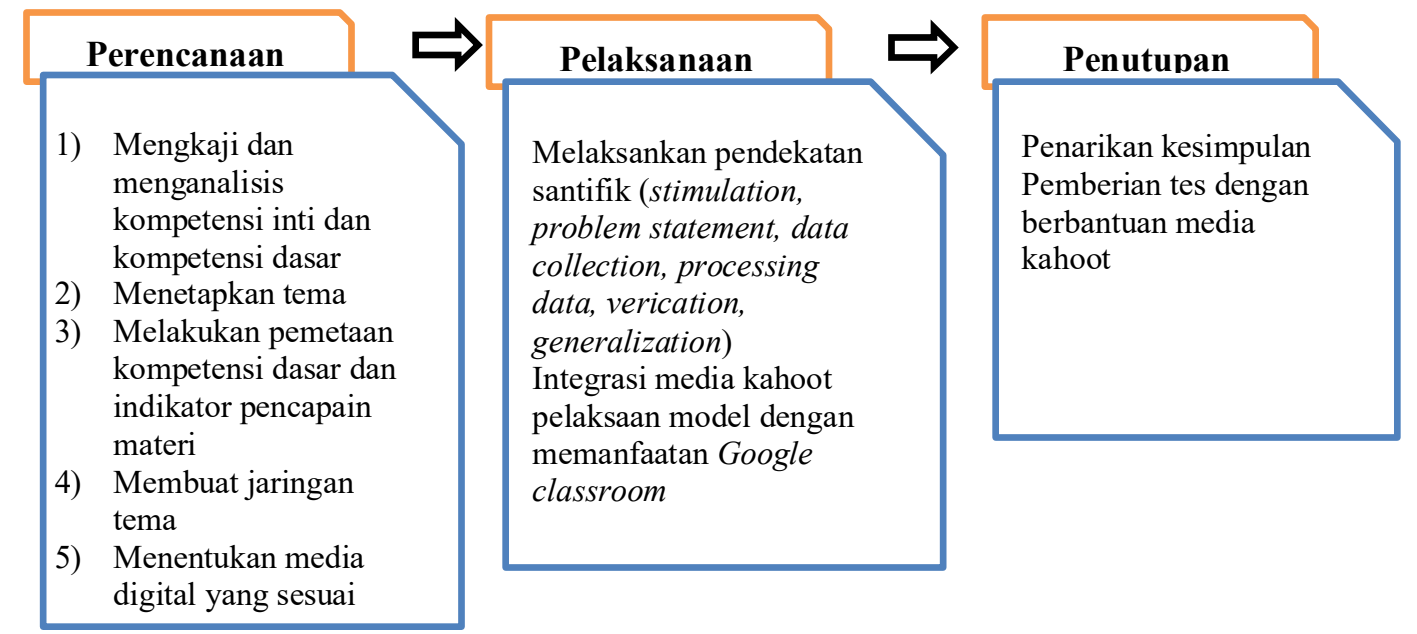

Gambar 1. Desain Pengembangan Model Pembelajaran 
Pembelajaran infusing blended learning dengan media google classroom dan kahoot! membuat peserta didik merasa tertantang karena setiap pertemuan peserta didik saling berkompetisi agar mendapat skor tertinggi dalam permainan di kahoot!. Pembelajaran dengan media kahoot! juga menyenangkan karena menurut peserta didik mereka bisa bermain sambil belajar sehingga pembelajaran IPS ini menjadi menyenangkan dan tidak membuat beban. Pembelajaran dengan media kahoot! ini banyak membawa dampak positif untuk peserta didik selain peserta didik menjadi mandiri, daya ingatpun menjadi lebih baik, meningkatkan percaya diri, dan juga pembelajaran dengan infusing blended learning dengan media google classroom dan kahoot! menjadi aktif, menyenangkan, dan menarik sehingga pembelajaran di kelas menjadi kondusif dan tidak membuat peserta didik jenuh atau bosan.

Berdasarkan data hasil pemantauan tindakan dan hasil belajar peserta didik dapat disimpulkan bahwa penggunaan infusing blended learning dengan media google classroom dan kahoot! telah berhasil meningkatkan hasil belajar IPS dan keaktifan peserta didik di kelas VII F SMP Negeri 92 Jakarta. Adapun data yang diperoleh dari setiap siklusnya sebagai berikut:

\section{1) Data Hasil Belajar Peserta Didik}

Berdasarkan penggunaan infusing blended learning dengan media google classroom dan kahoot! dalam pembelajaran IPS ditemukan peningkatan hasil belajar peserta didik di setiap siklusnya. Berikut hasil belajar setiap siklus yang telah dijabarkan pada tabel sebagai berikut:

Tabel 1. Hasil Belajar IPS Di Kelas Uji Coba

\begin{tabular}{cccc}
\hline $\begin{array}{c}\text { Uji } \\
\text { Coba }\end{array}$ & $\begin{array}{c}\text { Rata-Rata } \\
\text { Hasil Belajar }\end{array}$ & $\begin{array}{c}\text { Peserta Didik yang } \\
\text { Tuntas }\end{array}$ & $\begin{array}{c}\text { Presentase } \\
\text { Ketuntasan Hasil } \\
\text { Belajar }\end{array}$ \\
\hline I & 68 & 15 & $42 \%$ \\
\hline II & 74 & 24 & $67 \%$ \\
\hline III & 83 & 30 & $83 \%$ \\
\hline
\end{tabular}

Sedangkan hasil belajar siswa untuk kelas kontrol adalah sebagai berikut :

Tabel 2. Hasil Belajar IPS Di Kontrol

\begin{tabular}{cccc}
\hline $\begin{array}{c}\text { Uji } \\
\text { Coba }\end{array}$ & $\begin{array}{c}\text { Rata-Rata } \\
\text { Hasil Belajar }\end{array}$ & $\begin{array}{c}\text { Peserta Didik yang } \\
\text { Tuntas }\end{array}$ & $\begin{array}{c}\text { Presentase } \\
\text { Ketuntasan Hasil } \\
\text { Belajar }\end{array}$ \\
\hline I & 62 & 12 & $33 \%$ \\
\hline II & 68 & 20 & $56 \%$ \\
\hline III & 72 & 21 & $58 \%$ \\
\hline
\end{tabular}


Berdasarkan tabel 1 tentang hasil belajar IPS peserta didik dapat dilihat bahwa terdapat peningkatan pada setiap uji coba untuk rata-rata hasil belajar dan untuk presentase ketuntasan hasil belajar. Hal ini agar lebih jelas dapat disajikan dalam bentuk histogram sebagai berikut :

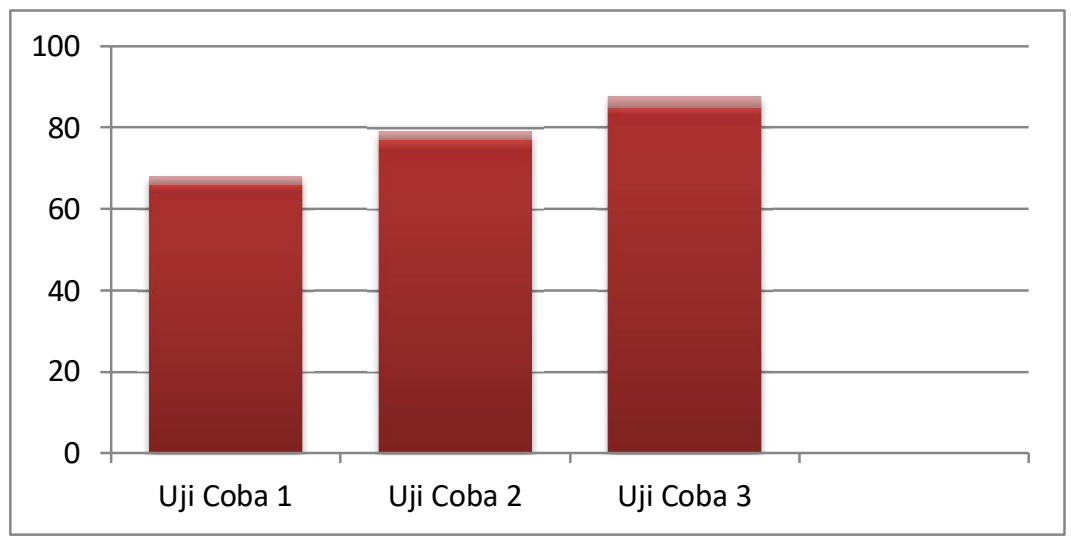

Gambar 2. Histogram Persentase Ketuntasan Hasil Belajar

Berdasarkan tabel dan histogram di atas dapat disimpulkan bahwa selama pelaksanaan uji coba model selalu mengalami peningkatan rata-rata hasil belajar dan presentase ketuntasan hasil belajar. Pada uji coba 1 rata-rata hasil belajar dan presentase ketuntasan masih jauh dari target yang telah ditentukan yaitu rata-ratanya 68 dengan presentase ketuntasan hasil belajar sebesar $42 \%$, maka dari itu penelitian dilanjutkan ke uji coba 2. Pada uji coba 2 rata-ratanya sudah melampaui KKM 72, namun pada uji coba 2 ini belum mencapai target IPH $\geq 80 \%$ peserta didik mencapai KKM 72. Uji coba 3 rata-rata hasil belajar dan presentase ketuntasan hasil belajar telah mencapai target IPH $\geq 80 \%$ peserta didik mencapai KKM 72 yaitu rata-ratanya 83 dengan presentase ketuntasan belajarnya $83 \%$. Dari data hasil belajar tersebut dapat dikatakan bahwa penggunaan media google classroom dan kahoot! dapat meningkatkan hasil belajar IPS.

\section{2) Data Presentase Keaktifan Peserta Didik}

Data presentase keaktifan peserta didik yang berhasil diperoleh selama melaksanakan uji coba mengalami peningkatan dalam setiap siklusnya. Berikut presentase keaktifan peserta didik setiap uji cobaa yang telah dijabarkan pada tabel berikut ini:

Tabel 3. Presentase Keaktifan Belajar Kelas Uji Coba

\begin{tabular}{|l|r|c|c|}
\hline Indilzator & Uji Coba 1 & Uji Coba 2 & Uji Coba 3 \\
\hline
\end{tabular}




\begin{tabular}{|l|c|c|c|c|c|c|c|c|c|}
\cline { 2 - 10 } & $\mathbf{1}$ & $\mathbf{2}$ & $\mathbf{3}$ & $\mathbf{1}$ & $\mathbf{2}$ & $\mathbf{3}$ & $\mathbf{1}$ & $\mathbf{2}$ & $\mathbf{3}$ \\
\hline Bertanya & $72 \%$ & $19 \%$ & $9 \%$ & $22 \%$ & $56 \%$ & $22 \%$ & $11 \%$ & $25 \%$ & $64 \%$ \\
\hline Menjawab & $67 \%$ & $22 \%$ & $11 \%$ & $25 \%$ & $58 \%$ & $17 \%$ & $11 \%$ & $28 \%$ & $61 \%$ \\
\hline Berpendapat & $69 \%$ & $17 \%$ & $14 \%$ & $22 \%$ & $58 \%$ & $20 \%$ & $14 \%$ & $28 \%$ & $58 \%$ \\
\hline Memecahkan masalah & $67 \%$ & $19 \%$ & $14 \%$ & $28 \%$ & $52 \%$ & $20 \%$ & $14 \%$ & $30 \%$ & $56 \%$ \\
\hline
\end{tabular}

Keterangan :

$1=$ Kurang Aktif $\quad 2=$ Cukup Aktif $\quad 3=$ Aktif

Sedangkan presentase keaktifan belajar siswa untuk kelas kontrol adalah sebagai berikut :

Tabel 4. Presentase Keaktifan Belajar Kelas Kontrol

\begin{tabular}{|l|c|c|c|c|c|c|c|c|c|}
\hline \multirow{2}{*}{ Indikator } & \multicolumn{3}{|c|}{ Uji Coba 1 } & \multicolumn{3}{|c|}{ Uji Coba 2 } & \multicolumn{3}{|c|}{ Uji Coba 3 } \\
\cline { 2 - 10 } & $\mathbf{1}$ & $\mathbf{2}$ & $\mathbf{3}$ & $\mathbf{1}$ & $\mathbf{2}$ & $\mathbf{3}$ & $\mathbf{1}$ & $\mathbf{2}$ & $\mathbf{3}$ \\
\hline Bertanya & $62 \%$ & $29 \%$ & $19 \%$ & $26 \%$ & $56 \%$ & $29 \%$ & $16 \%$ & $25 \%$ & $62 \%$ \\
\hline Menjawab & $72 \%$ & $19 \%$ & $9 \%$ & $22 \%$ & $56 \%$ & $22 \%$ & $11 \%$ & $25 \%$ & $64 \%$ \\
\hline Berpendapat & $67 \%$ & $22 \%$ & $11 \%$ & $25 \%$ & $58 \%$ & $17 \%$ & $11 \%$ & $28 \%$ & $61 \%$ \\
\hline Memecahkan masalah & $69 \%$ & $17 \%$ & $14 \%$ & $22 \%$ & $58 \%$ & $20 \%$ & $14 \%$ & $28 \%$ & $58 \%$ \\
\hline
\end{tabular}

Keterangan :

$1=$ Kurang Aktif $\quad 2$ = Cukup Aktif $3=$ Aktif

Berdasarkan tabel 4. data presentase keaktifan peserta didik selama uji coba mengalami peningkatan. Hal ini membuat penggunaan media google classroom dan kahoot! telah mampu meningkatkan presentase keaktifan peserta didik berdasarkan kemampuan bertanya, kemampuan menjawab, kemampuan berpendapat, dan kemampuan memecahkan masalah. Untuk melihat lebih terperinci peningkatan presentase peserta didik dalam setiap siklus, maka akan dijabarkan dengan histogram presentase keaktifan peserta didik berdasarkan kemampuan bertanya, kemampuan menjawab, kemampuan berpendapat, kemampuan memecahkan masalah sebagai berikut:

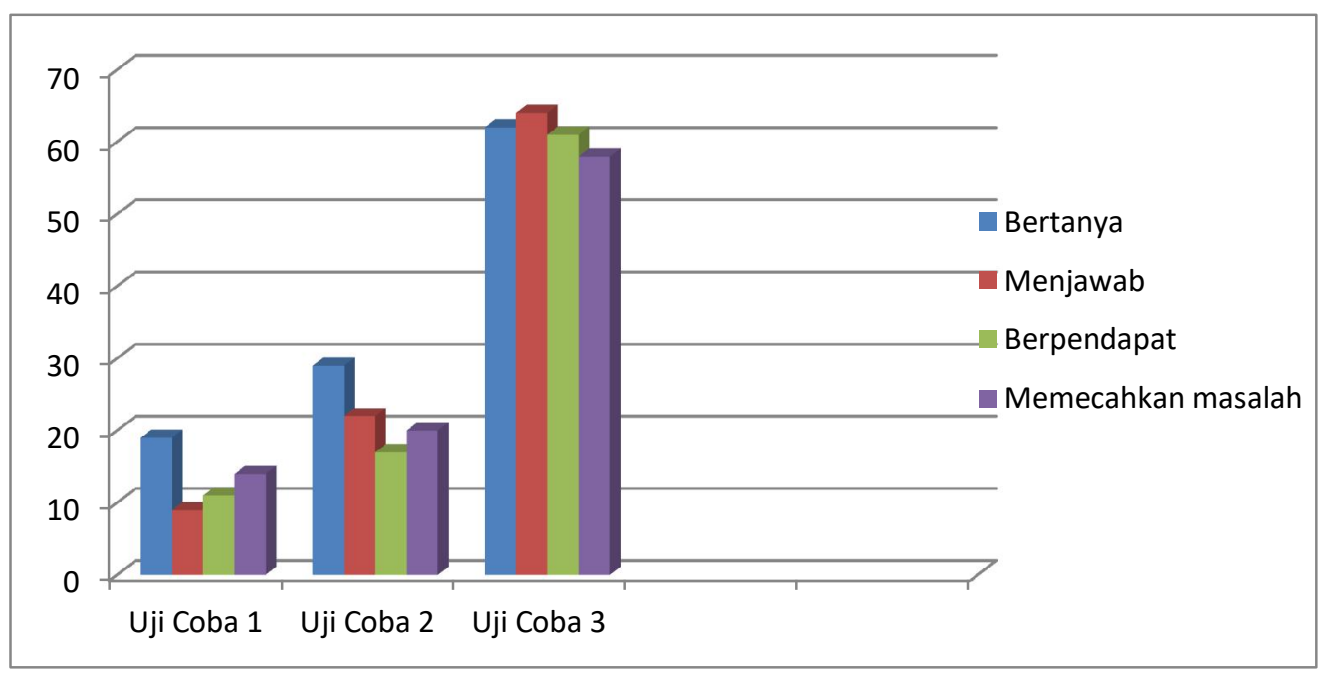


Berdasarkan gambar 3 tentang histogram presentase keaktifan peserta didik dalam aspek kemampuan menjawab, siklus 1 presentase kurang aktif sebesar $67 \%$ lebih tinggi dibandingkan cukup aktif sebesar $22 \%$ dan $11 \%$ untuk aktif. Pada siklus 2 keaktifan peserta didik dalam aspek kemampuan menjawab mengalami peningkatan lebih yaitu untuk presentase kurang aktif sebesar $25 \%$ dan presentase cukup aktif sebesar $58 \%$ hal ini menunjukan peserta didik yang cukup aktif lebih banyak dibandingkan kurang aktif, dan aktif sebanyak $17 \%$ mengalami peningkatan lebih baik lagi, yaitu presentase peserta didik yang kurang aktif menurun menjadi $11 \%$ lalu cukup aktif menjadi $25 \%$ dan aktif meningkat menjadi $64 \%$. Kenaikan presentase peserta didik menjadi lebih aktif di karenakan tindakan sudah dilaksanakan berulang-ulang sehingga peserta didik dan guru sudah mulai terbiasa melakukan alur pembelajaran dengan menggunakan media kahoot!! dalam pembelajaran IPS.

Penggunaan infusing blended learning dalam penelitian ini adalah model pembelajaran yang memvariasikan beberapa model pembelajaran kooperatif dan kontekstual dengan pendekatan saintifik berbantuan media digital (google classroom dan kahoot!) bermaksud untuk menggairahkan belajar siswa sehingga siswa akan lebih aktif berperan dalam mengikuti pembelajaran sesuai dengan karakteristik anak di era milenial yang memiliki ketertarikan yang tinggi dengan media digital berbasis internet. Antusias siswa dalam mengikuti pembelajaran akan meningkat jika didukung dengan penggunaan model pembelajaran yang bervariasi, penggunaan media yang sesuai dengan perkembangan zaman, tepat dengan materi dan menarik minat perhatian siswa sehingga pada gilirannya hasil belajar siswa dapat meningkat.

Berdasarkan hasil penelitian, penggunaan google classroom selain dapat meningkatkan hasil belajar siswa, juga dapat meningkatkan keaktifan belajar siswa, hal ini sejalan dengan penelitian yang dilakukan oleh Ari Sudibjo (2019) yang menyatakan bahwa penggunaan media pembelajaran berbasis google classroom dapat meningkatkan motivasi dan hasil belajar peserta didik. Selian itu, penelitian Maskarr dan Endah Wulantina (2019) juga memperkuat penelitian ini yang menyebutkan bahwa persepsi siswa dalam pembelajaran dengan menggunkan googloe classroom mendapatkan penilaian yang baik dari peserta didik yakni pembelajaran menjadi menarik, dan menumbuhkan motivasi, serta menumbuhkan sikap belajar mandiri, serta mampu meningkatkan pemahaman dan hasil belajar peserta didik.

Selain menggunakan google classroom, pembelajaran yang dilakukan dalam penelitian ini juga mengkombinaskiakan dengan penggunaan media kahoot!, penggunaan media kahoot! dalam pembelajaran juga dapat meningkatkan minat dan hasil belajar. Hal ini tentu memperkuat hasil penelitian yang dilakukan oleh Sriwigati (2019) tentang penggunaan media kahoot! untuk meningktkan hasil dan minat belajar siswa yang menunjukan bahwa terdapat peningkatkan hasil dan minat belajar siswa ketika menggunakan media kahiit dalam proses pembelajaran yang dilakukan. Pemilihan media kahoot! juga sejalan dengan penelitian yang dilakukan oleh Irwan (2019) yang menyatakan bahwa kahoot!! merupakan merupakan inovasi dibidang pembelajaran di dunia. Penggunakaan kahoot! dapat meningkatkan kemampuan berfikir dan belajar peserta didik sehingga perlu untuk dikembangkan.

Melalui infusing blended learning semua sumber belajar yang dapat memfasilitasi terjadinya pembelajaran dikembangkan, yakni pembelajaran dengan pendekatan teknologi pembelajaran dengan kombinasi sumber-sumber belajar tatap muka dengan pengajar maupun yang dimuat dalam media komputer, telepon seluler, video, dan media elektronik lainnya. 
Tujuan blended learning adalah memberikan kesempatan bagi pembelajar agar terjadi belajar mandiri, berkelanjutan, dan berkembang sepanjang hayat, sehingga belajar akan menjadi lebih efektif, efisien, dan menarik. Infusing blended learning dalam pembelajaran IPS dalam penelitin ini adalah pembelajaran IPS yang dikemas dengan model pembelajaran kontekstual dan kooperatif dengan pendekatan saintifik namun dalam pembelajaran menyisipkan atau memasukan materi dengan bantuan media digital yang terkoneksi internet. Hal ini dimaksudkan agar relevan dengan perkembangan revolusi industri 4.0 yang dicirikan dengan penggunaan teknologi informasi.

Infusing blended learning dalam pembelajaran IPS yang dikembangkan dilakukan melalui langkah-langkah:

1) Guru memberikan aperpsepsi, orientasi dan motivasi belajar serta acuan tentang materi yang akan dipelajari.

2) Peserta didik melakukan pengamatan atas suatu fenomena yang berupa gambar/video, lingkungan sekitar untuk mengidentifikasi hal-hal yang ingin diketahui dari hasil pengamatan berdasarkan kehidupan nyata siswa atau kontekstual.

3) Peserta didik dapat merumuskan pertanyaan berdasarkan suatu yang ingin diketahui ketika melakukan pengamatan.

4) Secara berkelompok melakukan diskusi dan mengumpulkan data atau informasi dengan berbagai teknik, seperti: membaca buku peserta didik, mencari di internet, wawancara dengan nara sumber atau melakukan pengamatan di lapangan.

5) Peserta didik diberi lembar kerjaindividu oleh guru yang harus dikerjakan dengan waktu yang telah ditentukan oleh guru. Hal ini membuat peserta didik mengumpulkan informasi dan untuk menguasai materi yang akan dipelajari.

6) Setelah lembar kerja dikumpulkan, Peserta didik dan guru mengadakan pembelajaran IPS dengan menggunakan media kahoot!.

7) Guru mengadakan permainan menjodohkan di dalam media kahoot!! yang berkaitan dengan materi masuknya Islam ke Indonesia, persebaran Islam di Indonesia, dan pengaruh Islam terhadap masyarakat Indonesia. Permainan ini dilakukan individu.

8) Setiap kelompok membuat mind map atau peta pikiran untuk membahas pemecahan masalah tersebut dan menjelaskannya. Dengan demikian siswa lebih mudah untuk menangkap materi dan memahaminya serta menyimpulkan materi.

9) Mengomunikasikan kesimpulan dengan cara mempresentasikan di depan kelas, menempel kesimpulan pada dinding kelas atau tempat yang telah disediakan sebagai wahana belajar peserta didik.

Penerapan infusing blended learning dalam IPS di samping untuk meningkatkan hasil belajar, bermanfaat pula untuk meningkatkan hubungan komunikasi. Komunikasi yang terjalin dapat lebih kuat antara pendidik dengan peserta didik dari pada pembelajaran konvensional yang dilakukan secara klasikal di kelas atau menggunakan online sepenuhnya (Rovai dan Jordan, 2004). Infusing blended learning merupakan pilihan untuk meningkatkan efektivitas, efisiensi, dan daya tarik yang lebih besar dalam berinteraksi antar manusia dalam lingkungan belajar yang beragam. Blended learning menawarkan kesempatan belajar untuk menjadi baik secara bersamasama dan terpisah, pada waktu yang sama maupun berbeda. Sebuah komunitas belajar dapat dilakukan oleh pelajar dan pengajar yang dapat berinteraksi setiap saat dan di mana saja dengan memanfaatkan komputer maupun perangkat lain (seperti smartphone) sebagai fasilitasi belajar.

Pada penggunaan infusing blended learning dalam IPS, siswa dapat mengembangkan dan melatih berbagai ketrampilan. Siswa tidak hanya sebagai objek belajar yang hanya mendengarkan dan menerima materi saja melainkan juga sebagai subjek belajar karena siswa bisa menjadi teman diskusi aktif bagi pasangannya. Dalam diskusi, siswa dilatih untuk bekerja sama, karena bukan materi saja yang dipelajari melainkan tuntutan untuk manfaat yang dapat diperoleh dengan menerapkan infusing blended learning pada pelajaran IPS antara lain adalah: 
(1) membantu menjadikan gambar konkrit sesuai ralita yang sulit didapatkan di sekolah, (2) memungkinkan pengulangan materi dan pengkayaan materi bagi siswa, (3) dapat mendukung pembelajaran individual maupun kelompok, (4) dapat dijadikan media pembelajaran media pembelajaran yang efektif, (5) membanguan pembelajaran yang "enjoyment" atau "joyful learning" sesuai dengan revolusi industri 4.0. Sedangkan kelemahan dalam pembelajaran infusing blended learning ini yaitu (1) sangat bergantung dengan akses internet, (2) guru harus kreatif mencari materi yang relevan dengan konten materi yang ada dalam kompetensi dasar atau tema yang diajarkan, (3) guru harus memiliki pengetahuan dan ketrampilan dalam menggunakan media pembelajaran digital.

\section{3) Keterbatasan Penelitian}

Berdasarkan pelaksanaan penelitian dan catatan lapangan, maka keterbatasan dalam penelitian di antaranya sebagai berikut:

1) Pengembangan model pembelajaran ini dilakukan baru satu kelas uji coba dan satu kelas kontrol dalam satu sekolah yang sama.

2) Sulit mengontrol pengguna google classroom sebagai infusing blended learning karena tidak dapat diamati secara langsung.

3) Penggunaan media kahoot! sebagai infusing blended learning harus menciptakan permainan yang kreatif dan inovatif agar pembelajaran tidak monoton.

4) Penerapan infusing blended learning dengan media google classroom dan kahoot! harus menggunakan jaringan internet dan gadget, jika sekolah tidak memfasilitasi maka pembelajaran akan terhambat.

\section{Simpulan}

Pengembangan model pembelajaran yang berorientasi dengan revolusi industri 4.0 yang dicirikan dengan penggunaan intenet dan digitalisasi pembelajaran adalah dengan menggunakan model pembelajaran infusing blended learning dimana dalam hal ini adalah dengan mengitegrasikan media pembelajaran digital berupa google classroom dan kahoot! dalam proses pembelajaran yang dilakukan oleh guru. Model pembelajaran IPS yang relevan dengan tuntutan revolusi industri 4.0 adalah dengan menggunakan model pembelajaran kooperatif dan kontekstual dengan pendekatan saintifik namun berbantuan media digital (google classroom dan kahoot!) sebagai bentuk adapatasi terhadap perkembangan teknologi informasi. Berdasarkan hasil penelitian menunjukan bahwa blended learning dengan menggunakan media google classroom dan kahoot! dapat meningkatkan hasil belajar dan juga keaktifan peserta didik. Sehingga penggunaan model pembelajaran blended learning dengan mengintegrasikan google classroom dan kahoot! dalam pembelajaran IPS dapat digunakan sebagai alternative guru dalam melaksanakan pembelajaran di era era revolusi indutri 4.0.

\section{Daftar Pustaka}

[1]. Centinkaya, Murat. (2016). Design of Personalized Blended Learning Environments Based On Web-Assisted Modelling In Science Education International. Journal of Evaluation and Research in Education, 5(4), 323-330.

[2]. Dick, W and L. Carey, J. O. Carey. (2005). The systematic Design of Instruction. New York: Logman

[3]. Hosnan. (2014). Pendekatan Saintifik dan Kontekstual Dalam Pembelajaran Abad 21. Jakarta: Ghalia Indonesia. 
[4]. Irwan. (2019). Implementasi kahoot! Sebagai inovasi pembelajaran. Journal Of Civic Education, 2(1), 126-140.

[5]. Maskar dan Endah Wulantina. (2019). Persepsi Peserta Didik Terhadap Metode Blended Learning Dengan Google Classroom. Jurnal Inomatika, 1(2), 110-121.

[6]. Munir. (2017). Pembelajaran Digital. Bandung: Alfabeta.

[7]. Sudibjo, Ari. (2019). Penggunaan Media Pembelajaran Berbasis Google Classroom Pada Materi Alat Optic Untuk Meningkatkan Motivasi Dan Hasil Belajar Siswa Di SMP Negeri 4 Surabaya. Journal Education and Development, 7(3), 278-284.

[8]. Muhammad, Yoga. Tetep. (2018). Implementation of Kahoot Application to Improving of Interest of Civic Education Learning (Experimental Research in Class xi of SMA Negeri 1 Garut). Jurnal Civicos Vol 2 No. 1. Tahun 2018. https://journal.institutpendidikan.ac.id/index.php/journalcss/article/view/399/437.

DOI: DOI: https://doi.org/10.31980/2655-7304.v2i1.399. DOI (PDF): https://doi.org/10.31980/2655-7304.v2i1.399.g437

[9]. Wasis. (2018). Learning Based Blended Learning. Jakarta: Raja Grafindo.

[10].Wigati, Sri. (2019). Penggunaan Media Game Kahoot Untuk Meningkatkan Hasil dan Minat Belajar Matematika. Jurnal program Studi Matematika, 8(3), 457 - 464.

[11]. Wright, Brenda. (2017). Blended Learning: Student Perception Of Face-To-Face And Online Efl Lessons. Indonesian Journal of Applied Linguistics, 7(1), 64-71 